BMC

Evolutionary Biology

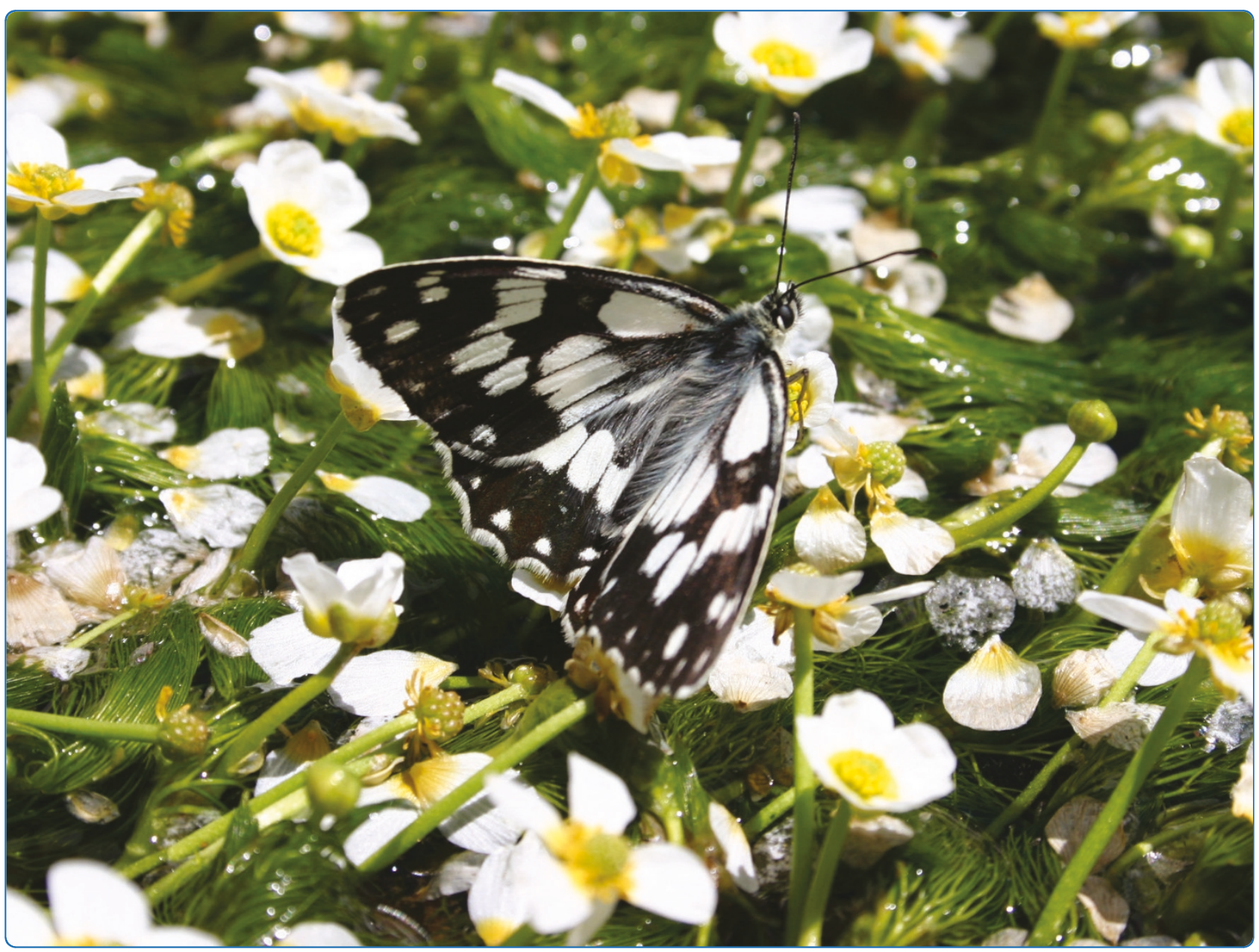

From Africa to Europe and back: refugia and range shifts cause high genetic differentiation in the Marbled White butterfly Melanargia galathea Habel et al. 


\title{
From Africa to Europe and back: refugia and range shifts cause high genetic differentiation in the Marbled White butterfly Melanargia galathea
}

\author{
Jan C Habel ${ }^{1 *}$, Luc Lens ${ }^{2}$, Dennis Rödder ${ }^{3,4}$ and Thomas Schmitt ${ }^{3}$
}

\begin{abstract}
Background: The glacial-interglacial oscillations caused severe range modifications of biota. Thermophilic species became extinct in the North and survived in southern retreats, e.g. the Mediterranean Basin. These repeated extinction and (re)colonisation events led to long-term isolation and intermixing of populations and thus resulted in strong genetic imprints in many European species therefore being composed of several genetic lineages. To better understand these cycles of repeated expansion and retraction, we selected the Marbled White butterfly Melanargia galathea. Fourty-one populations scattered over Europe and the Maghreb and one population of the sibling taxon M. lachesis were analysed using allozyme electrophoresis.

Results: We obtained seven distinct lineages applying neighbour joining and STRUCTURE analyses: (i) Morocco, (ii) Tunisia, (iii) Sicily, (iv) Italy and southern France, (v) eastern Balkans extending to Central Europe, (vi) western Balkans with western Carpathian Basin as well as (vii) south-western Alps. The hierarchy of these splits is well matching the chronology of glacial and interglacial cycles since the Günz ice age starting with an initial split between the galathea group in North Africa and the lachesis group in Iberia. These genetic structures were compared with past distribution patterns during the last glacial stage calculated with distribution models.

Conclusions: Both methods suggest climatically suitable areas in the Maghreb and the southern European peninsulas with distinct refugia during the last glacial period and underpin strong range expansions to the North during the Postglacial. However, the allozyme patterns reveal biogeographical structures not detected by distribution modelling as two distinct refugia in the Maghreb, two or more distinct refugia at the Balkans and a close link between the eastern Maghreb and Sicily. Furthermore, the genetically highly diverse western Maghreb might have acted as source or speciation centre of this taxon, while the eastern, genetically impoverished Maghreb population might result from a relatively recent recolonisation from Europe via Sicily.
\end{abstract}

Keywords: climatic oscillations, barriers, phylogeography, Melanargia galathea, Melanargia lachesis, allozyme electrophoresis, climate envelope modelling

\section{Background}

The impacts of climatic oscillations on the earth's biota have been intensively studied [1]. In the western Palaearctic, thermophilic organisms went extinct over major parts of Central and North Europe during cold stages and survived in the lowlands of lower latitudes in often distinct refugia [2-6]. Molecular studies revealed that most of

\footnotetext{
* Correspondence: Janchristianhabel@gmx.de

'Musée national d'histoire naturelle Luxembourg, L-2160 Luxembourg, Luxembourg

Full list of author information is available at the end of the article
}

these taxa exclusively survived glacial periods south of the European high mountain chains in the Iberian, Italian and Balkan peninsulas, and some even in additional extraMediterranean refugia $[7,8]$. The long-term isolation of populations in these retreats over many thousands of years resulted in genetic differentiation [5]. During the warmer interglacial periods, species expanded their distribution ranges northwards and extended their different genetic lineages over more northern areas $[9,10]$.

In contrast to the three more intensively studied Mediterranean refugia of southern Europe (Iberia, peninsular
C Biomed Central 
Italy and the Balkans), little is known about North African refugia and the biogeographical relation between the Maghreb and southern Europe separated by the two narrow sea straits of Gibraltar and Sicily. It has been shown that the Maghreb is often sub-structured following an east-west [e.g. [11-13]] or south-north differentiation pattern [e.g. [5,14]]; in some cases, genetic continuity was demonstrated between the Maghreb and Sicily [e.g. $[15,16]]$. Other studies underline the important role of Sicily as diversification centre for European taxa unravelling deep genetic splits between this island and peninsular Italy (e.g. Erinaceus europaeus: [17]; Pseudepidalea viridis: $[18,19])$. Few molecular analyses also reveal the outstanding importance of North Africa as a refugium for thermophilic species during glacial periods [e.g. [12,14,20,21]]. However, most studies focus either on the Maghreb or the southern European refugia and do not combine the distribution of species all over north-western Africa and throughout Europe.

To study the biogeographical importance of the Maghreb region and its connection with Europe, we selected the Marbled White butterfly species complex Melanargia galathea (Linnaeus, 1758) and Melanargia lachesis (Hübner, 1790) as a model system using two analytical tools (allozyme polymorphisms and distribution modelling). Today, $M$. galathea is widely distributed from the Maghreb region (mountain ranges of Morocco, Algeria and Tunisia) $[22,23]$ to the English Midlands [24], and from the Pyrenees [25] to the Baltic Sea in Poland [26]. On the Iberian Peninsula, $M$. galathea is replaced by its sibling species $M$. lachesis. Thus, the Italian peninsula is the only possible link between North Africa and Europe for M. galathea.

Previous molecular studies on these butterflies based on allozyme polymorphisms supported the sibling species status of both taxa and revealed two genetic groups in M. galathea, one western and one eastern group, indicating an Italian and a Balkan refugium [27], with further substructures in the Balkan region [28]. Preliminary data for the western Maghreb showed the highest known values of genetic variability in this region [29]. Based on these data, we hypothesized a Maghreb origin of the species and colonisation of Europe via Sicily and Italy. However, these previous studies lack populations from the eastern Maghreb, Sicily, Italy and southern France. In this article we combine an allozyme data set covering most of the recent distribution of the species with climate envelope models to test the previously postulated biogeographical scenario of refugia and barriers during the last ice ages until today, addressing the following questions:

(i) Which refugia are of importance for the glacial survival of the M. galathea /lachesis species complex during the subsequent glacial periods?

(ii) Is there any evidence of genetic structuring within the North African and Italian refugia? (iii) Which routes of expansion and retraction followed the butterfly throughout time?

\section{Results \\ Phylogeographic analyses}

All enzyme loci had banding patterns consistent with known quaternary structures. While most loci were inherited autosomally, 6PGDH and ME were located on the $\mathrm{Z}$ chromosome so that hemizygous females (but not males) had a single copy [27]. No general linkage disequilibrium was observed for any locus (all $p>0.05$ after Bonferoni correction). A total of 13 analysed loci were polymorphic, but two loci (FUM, GPDH) were monomorphic throughout all samples. Allele frequencies for each enzyme and population are given in an additional file 1 .

When calculating parameters of genetic diversity, all 15 loci were used. The genetic diversities of populations showed strong variability among populations of different regions, and standard deviations were high if compared against means (ratio standard deviation against means: $A$ 9.0\%; $H_{\mathrm{e}} 12.9 \% ; H_{\mathrm{o}} 18.3 \%$; $\left.P_{\text {tot }} 18.1 \% ; P_{95} 15.6 \%\right)$. Values for all populations analysed are given in Table 1 , overall means in Table 2.

A neighbour joining phenogram based on allele frequencies (Figure 1) showed a first split between $M$. galathea and M. lachesis with a genetic distance [28] of about 0.9. The second split between M. galathea populations from Tunisia and Sicily on the one hand and all remaining $M$. galathea populations on the other was in average about half of the genetic distance of the first split. The outgroup $M$. lachesis routing the tree also supports this split being the first one in M. galathea. The Tunisia - Sicily group showed a further genetic differentiation between these two geographic regions. All these splits are supported by bootstrap values. The remaining populations split into five groups, the populations from Morocco and four European groups: (i) mainland Italy and southern France (Condat), (ii) western Balkans and western Carpathian Basin, (iii) eastern Balkans, Romania and Central Europe, as well as (iv) south-western Alps (Col de Tende). The latter group is the only one well supported by bootstrapping. Unexpectedly, the populations from Morocco are not well distinguishable in this tree from the western Balkan group. Three populations are not matching any of these groups: the north-eastern French population Lorry and the southern German population Bossler are intermediate between groups iii and iv, and the southern Calabrian population St. Giorgio shows some traits of the Sicily-Tunisia group thus not clustering together with the other populations from mainland Italy. These three populations are thought to be of hybrid origin between the respective genetic groups.

STRUCTURE plots (for $\mathrm{K}=2$ to $\mathrm{K}=8$ ) support the topology of the neighbour joining phenogram (Figure 2); 
Table 1 Sampling location and five parameters of genetic diversity for 41 populations of Melanargia galathe a from its western Palaearctic distribution area and one population of $M$. lachesis from the Pyrenees: number of individuals analysed $(N)$, mean number of alleles per locus $(A)$, percentage of expected $\left(H_{e}\right)$ and observed $\left(H_{o}\right)$ heterozygosity, percentage of polymorphic loci not exceeding $95 \%\left(P_{95}\right)$ and total number of polymorphic loci $\left(P_{\text {tot }}\right)$

\begin{tabular}{|c|c|c|c|c|c|c|c|c|c|c|}
\hline Region & Location & Running Nr. & $\begin{array}{l}\text { Long. (N) } \\
\text { Lat. (E/W) }\end{array}$ & Date of sampling & $N$ & $A$ & $H_{e}(\%)$ & $H_{o}(\%)$ & $P_{95}(\%)$ & $P_{\text {tot }}(\%)$ \\
\hline \multirow[t]{4}{*}{ Morocco } & M-Oukaimeden & 1 & $31.12 ; 7.52 \mathrm{~W}$ & $23-V-05$ & 36 & 2.33 & 20.5 & 20.6 & 46.7 & 46.7 \\
\hline & M-Naour & 2 & $32.29 ; 5.56 \mathrm{~W}$ & $26-V-05$ & 36 & 2.33 & 17.0 & 13.5 & 33.3 & 53.3 \\
\hline & M-Bekrite & 3 & $33.05 ; 5.13 \mathrm{~W}$ & $29-V-05$ & 36 & 2.53 & 17.2 & 18.5 & 33.3 & 53.3 \\
\hline & M-Timhadite & 4 & $33.14 ; 5.03 \mathrm{~W}$ & $29-V-05$ & 36 & 2.33 & 18.7 & 17.7 & 33.3 & 60.0 \\
\hline \multirow[t]{5}{*}{ Tunisia } & T-Ain Draham & 5 & $36.46 ; 8.42 \mathrm{E}$ & $23-V-10$ & 27 & 2.20 & 17.6 & 15.6 & 40.0 & 53.3 \\
\hline & T-Nebeur & 6 & $36.18 ; 8.46 \mathrm{E}$ & $26-V-10$ & 40 & 2.00 & 12.3 & 9.9 & 26.7 & 60.0 \\
\hline & T-Table de Yagurta & 7 & $35.45 ; 8.23 \mathrm{E}$ & $25-V-10$ & 40 & 2.13 & 13.6 & 10.6 & 40.0 & 53.3 \\
\hline & T-Thala & 8 & $35.34 ; 8.41 \mathrm{E}$ & $25-V-10$ & 40 & 1.80 & 12.5 & 12.1 & 26.7 & 40.0 \\
\hline & T-Béja & 9 & $36.44 ; 8.54 \mathrm{E}$ & $28-V-10$ & 40 & 1.86 & 13.6 & 9.8 & 33.3 & 40.0 \\
\hline \multirow[t]{3}{*}{ Sicily } & I-Valledomo & 10 & $37.45 ; 13.53 \mathrm{E}$ & $4-\mathrm{VII}-07$ & 40 & 2.13 & 14.5 & 13.2 & 40.0 & 53.3 \\
\hline & I-Francavilla & 11 & $37.53 ; 15.07 \mathrm{E}$ & $5-\mathrm{VII}-07$ & 30 & 2.26 & 17.8 & 14.8 & 26.7 & 66.7 \\
\hline & I-Reitano & 12 & $37.58 ; 14.20 \mathrm{E}$ & 26-VI-07 & 40 & 2.00 & 15.0 & 12.2 & 33.3 & 46.7 \\
\hline \multirow[t]{6}{*}{ Italy } & I-St. Giorgio & 13 & $38.17 ; 15.59 \mathrm{E}$ & $6-\mathrm{VIII}-07$ & 40 & 2.13 & 17.1 & 17.2 & 33.3 & 40.0 \\
\hline & I-Mormanno & 14 & $39.54 ; 15.58 \mathrm{E}$ & $7-\mathrm{VII}-07$ & 40 & 2.66 & 21.3 & 15.6 & 53.3 & 73.3 \\
\hline & I-Napoli & 15 & $41.08 ; 14.19 \mathrm{E}$ & $7-\mathrm{VIII}-07$ & 20 & 2.13 & 18.2 & 13.3 & 40.0 & 46.7 \\
\hline & I-Rieti & 16 & $42.25 ; 12.53 \mathrm{E}$ & $8-\mathrm{VII}-07$ & 40 & 2.20 & 17.8 & 17.4 & 33.3 & 53.3 \\
\hline & I-Consuma & 17 & $43.48 ; 11.36 \mathrm{E}$ & $8-V I I-07$ & 40 & 2.20 & 19.2 & 17.5 & 40.0 & 60.0 \\
\hline & I-Verona & 18 & $45.31 ; 10.55 \mathrm{E}$ & $9-\mathrm{VII}-07$ & 40 & 2.13 & 17.7 & 13.5 & 40.0 & 46.7 \\
\hline \multirow[t]{3}{*}{ France } & F-Col de Tende & 19 & $44.09 ; 7.34 \mathrm{E}$ & $31-\mathrm{VII}-03$ & 40 & 2.13 & 17.7 & 12.1 & 33.3 & 40.0 \\
\hline & F-Condat & 20 & $45.20 ; 2.45 \mathrm{E}$ & 11-VII-08 & 27 & 1.86 & 13.8 & 10.6 & 26.7 & 46.7 \\
\hline & F-Lorry & 21 & 49.00; 6.06E & 17-VI-03 & 40 & 2.06 & 17.6 & 15.3 & 33.3 & 40.0 \\
\hline \multirow[t]{8}{*}{ Central Europe } & L-Niederanven & 22 & $49.39 ; 6.16 \mathrm{E}$ & 13-VI-03 & 32 & 2.00 & 18.4 & 17.1 & 33.3 & 40.0 \\
\hline & D-Niederehe & 23 & $50.18 ; 6.48 \mathrm{E}$ & 18-VII-03 & 18 & 1.86 & 18.2 & 16.7 & 33.3 & 33.3 \\
\hline & D-Bossler & 24 & 48.36; 9.36E & VII-04 & 40 & 2.00 & 18.5 & 17.0 & 40.0 & 40.0 \\
\hline & D-Buchenberg & 25 & $50.43 ; 11.40 \mathrm{E}$ & VII-03 & 40 & 2.33 & 19.3 & 16.4 & 33.3 & 40.0 \\
\hline & A-Jadersdorf & 26 & $46.40 ; 13.18 \mathrm{E}$ & 18-VIII-04 & 40 & 2.00 & 13.5 & 12.6 & 33.3 & 33.3 \\
\hline & A-Hochobir & 27 & $46.30 ; 14.30 \mathrm{E}$ & 23-VIII-04 & 40 & 2.06 & 14.6 & 13.3 & 26.7 & 46.7 \\
\hline & A-Schöckl & 28 & $47.12 ; 15.28 \mathrm{E}$ & 22-VIIII-04 & 40 & 2.13 & 17.0 & 15.7 & 33.3 & 40.0 \\
\hline & A-Leithagebirge & 29 & $47.57 ; 16.39 \mathrm{E}$ & $31-\mathrm{VII}-03$ & 14 & 1.86 & 14.8 & 13.6 & 33.3 & 40.0 \\
\hline Hungary & H-Csákvár & 30 & $47.24 ; 18.26 \mathrm{E}$ & $13-\mathrm{VII}-04$ & 40 & 2.33 & 17.2 & 15.9 & 33.3 & 46.7 \\
\hline \multirow[t]{2}{*}{ western Balkans } & SLO-Postojna & 31 & $45.47 ; 14.12 \mathrm{E}$ & 15-VII-04 & 40 & 2.00 & 14.4 & 13.5 & 33.3 & 40.0 \\
\hline & MNE-Durmitor & 32 & $43.10 ; 19.08 \mathrm{E}$ & 10-VII-03 & 12 & 1.86 & 14.8 & 14.5 & 26.7 & 33.3 \\
\hline \multirow[t]{6}{*}{ Romania } & RO-Hoteni & 33 & $47.38 ; 24.02 \mathrm{E}$ & $25-\mathrm{VII}-04$ & 40 & 1.93 & 17.9 & 20.5 & 33.3 & 33.3 \\
\hline & RO-Cluj & 34 & $46.45 ; 23.35 E$ & $23-\mathrm{VII}-04$ & 40 & 2.13 & 18.3 & 17.7 & 40.0 & 40.0 \\
\hline & RO-Voslobeni & 35 & $46.40 ; 25.38 \mathrm{E}$ & 29-VII-04 & 40 & 1.86 & 18.5 & 18.6 & 33.3 & 40.0 \\
\hline & RO-Pasul Predelus & 36 & $45.35 ; 26.09 E$ & 31-VII-04 & 40 & 2.33 & 20.4 & 18.8 & 33.3 & 40.0 \\
\hline & RO-Porta di Fier Transilvanici & 37 & $45.31 ; 22.39 \mathrm{E}$ & $15-\mathrm{VII}-04$ & 40 & 2.06 & 19.1 & 19.2 & 33.3 & 40.0 \\
\hline & RO-Inelet & 38 & $44.58 ; 22.29 \mathrm{E}$ & 9-VIII-04 & 19 & 1.80 & 19.2 & 16.0 & 33.3 & 40.0 \\
\hline \multirow[t]{3}{*}{ Bulgaria } & BG-Milanovo & 39 & $43.05 ; 23.23 \mathrm{E}$ & $10-\mathrm{VIII-04}$ & 40 & 2.06 & 17.8 & 17.3 & 33.3 & 40.0 \\
\hline & BG-Karandila & 40 & $42.43 ; 26.20 \mathrm{E}$ & 3-VIII-04 & 40 & 2.06 & 18.4 & 17.1 & 33.3 & 40.0 \\
\hline & BG-Trigrad & 41 & $41.36 ; 24.17 \mathrm{E}$ & 7-VIII-04 & 40 & 2.06 & 16.5 & 16.5 & 33.3 & 33.3 \\
\hline lachesis & E-Col de Perbes* & 42 & $42.23 ; 1.13 \mathrm{E}$ & 19-VII-03 & 40 & 2.26 & 20.8 & 17.6 & 40.0 & 40.0 \\
\hline
\end{tabular}

* M. lachesis 
Table 2 Means of sample sizes and genetic diversities of the different genetic groups of Melanargia galathea and $M$. lachesis; $p$ values of Kruskal Wallis ANOVAs among groups are given

\begin{tabular}{lcccccc}
\hline & $\boldsymbol{N}$ & $\boldsymbol{A}$ & $\boldsymbol{H}_{\mathbf{e}}$ & $\boldsymbol{H}_{\mathbf{o}}$ & $\boldsymbol{P}_{\mathbf{9 5}}$ & $\boldsymbol{P}_{\text {tot }}$ \\
\hline All & $36.0 \pm 7.9$ & $2.10 \pm 0.19$ & $17.0 \pm 2.2$ & $15.3 \pm 2.8$ & $34.5 \pm 5.4$ & $45.2 \pm 9.4$ \\
\hline Morocco & $36.0 \pm 0.0$ & $2.38 \pm 0.10$ & $18.4 \pm 1.6$ & $17.6 \pm 3.0$ & $36.7 \pm 6.7$ & $53.3 \pm 5.4$ \\
Tunisia & $37.4 \pm 7.8$ & $2.00 \pm 0.17$ & $13.9 \pm 2.1$ & $11.6 \pm 2.4$ & $33.3 \pm 6.7$ & $49.3 \pm 8.9$ \\
Sicily & $37.7 \pm 5.8$ & $2.13 \pm 0.13$ & $15.8 \pm 1.8$ & $13.4 \pm 1.3$ & $33.3 \pm 6.6$ & $55.6 \pm 10.2$ \\
Italy + SE France & $35.3 \pm 8.3$ & $2.19 \pm 0.24$ & $17.9 \pm 2.3$ & $15.1 \pm 2.6$ & $38.1 \pm 8.3$ & $52.4 \pm 11.2$ \\
SW Alps & 40 & 2.13 & 17.7 & 12.1 & 33.3 & 40.0 \\
eastern Balkans + Central Europe & $36.8 \pm 7.4$ & $2.04 \pm 0.15$ & $17.8 \pm 1.7$ & $16.9 \pm 2.0$ & $33.7 \pm 2.9$ & $38.7 \pm 3.6$ \\
western Balkans & $26.5 \pm 15.6$ & $2.01 \pm 0.22$ & $15.3 \pm 1.3$ & $14.4 \pm 1.1$ & $31.6 \pm 3.3$ & $40.0 \pm 5.5$ \\
p (Kruskal Wallis ANOVA) & 0.33 & 0.044 & 0.019 & 0.004 & 0.65 & $<0.001$ \\
\hline eastern Balkans + Romania & $35.7 \pm 8.4$ & $2.05 \pm 0.15$ & $17.1 \pm 2.2$ & $15.5 \pm 1.8$ & $33.3 \pm 3.8$ & $39.0 \pm 4.6$ \\
Central Europe & $37.7 \pm 7.0$ & $2.03 \pm 0.16$ & $18.5 \pm 1.1$ & $18.0 \pm 1.4$ & $34.0 \pm 2.2$ & $38.5 \pm 2.9$ \\
p (Kruskal Wallis ANOVA) & 0.56 & $>0.99$ & 0.31 & 0.011 & 0.75 & 0.87 \\
\hline M. lachesis & 40 & 2.26 & 20.8 & 17.6 & 40.0 & 40.0 \\
\hline
\end{tabular}

the sequence of splits of STRUCTURE groups is mostly reflecting the genetic distances in the tree. Additionally, the samples from Morocco are consistently separated as one group from all other $M$. galathea populations from $\mathrm{K}=5$ onwards. However, the STRUCTURE analysis is not able to distinguish the western Balkan group from the eastern Balkans, Romania and Central Europe group. Furthermore, STRUCTURE did not reflect the hybrid origin of three populations mentioned above: St.
Giorgio (13) is grouped with all other populations from Italy, Bossler (24) with all populations from Central and south-eastern Europe and Lorry (21) is part of the south-western Alps group.

The overall differentiation among all populations including $M$. lachesis was strong $\left(F_{\mathrm{ST}}: 0.179, p<0.001\right)$; excluding this outgroup population only decreased this value marginally $\left(F_{\mathrm{ST}}: 0.169, p<0.001\right)$ (Table 3$)$. Hierarchical variance analyses well supported the hierarchical

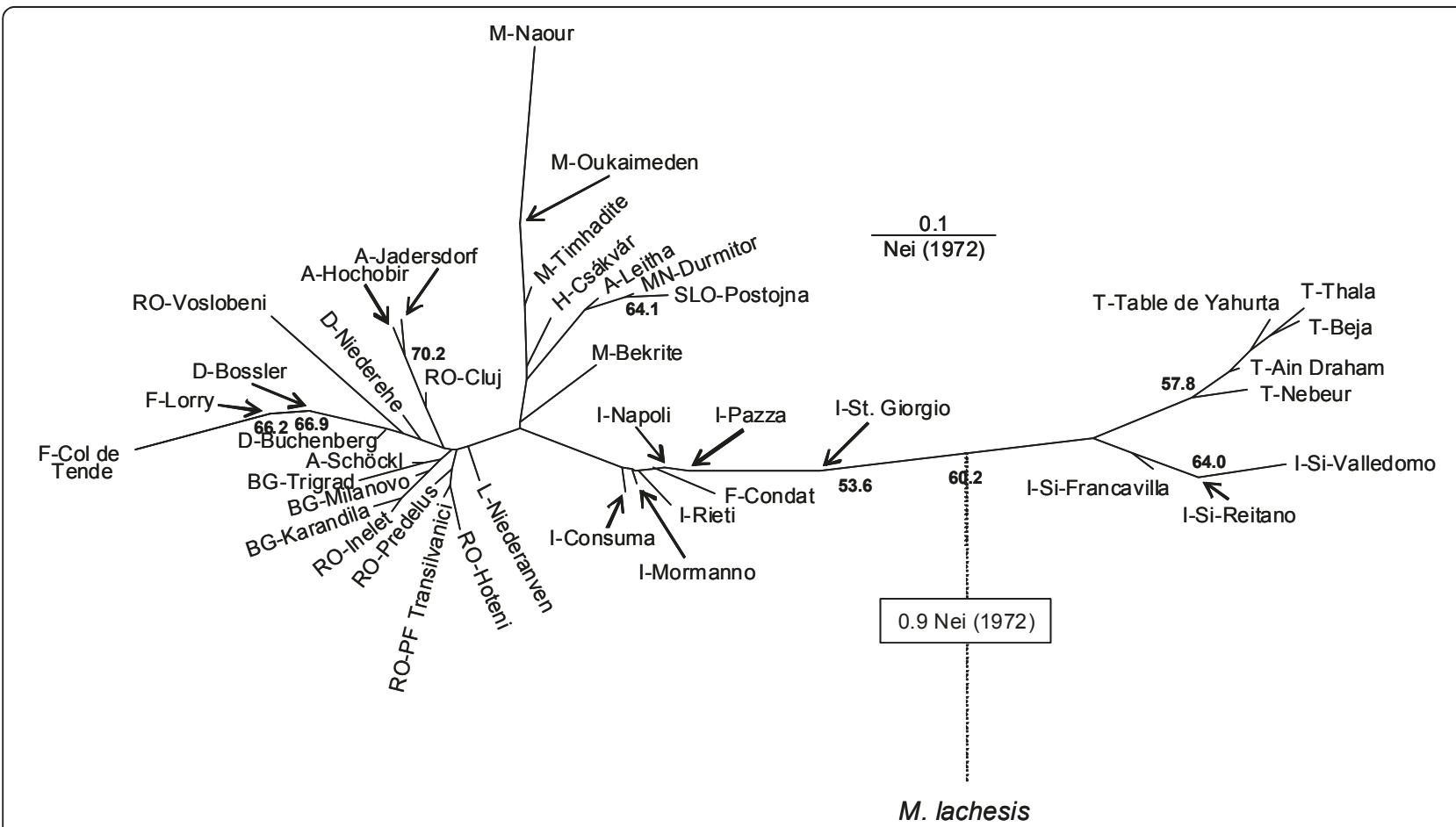

Figure 1 Neighbour-joining dendrogram of Melanargia galathea and M. lachesis. The phenogram is based on the genetic distances (Nei, 1972) [56] of 41 populations of M. galathea and one population of M. lachesis. 


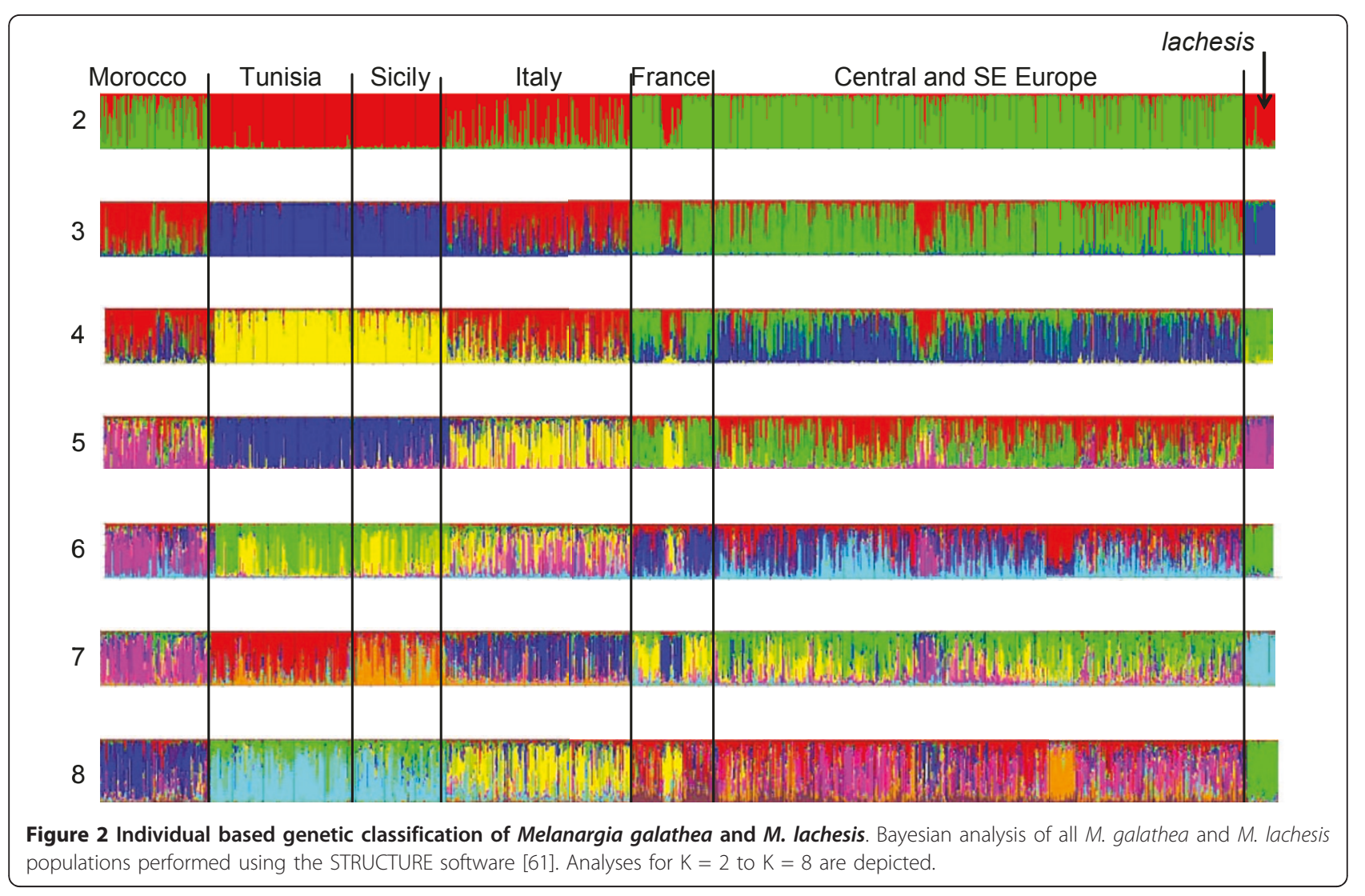

Table 3 Analyses of molecular variance for all Melanargia galathea populations and one population of M.lachesis

\begin{tabular}{|c|c|c|c|}
\hline Group & $\begin{array}{l}\text { among populations } \\
\left(F_{\mathrm{ST}}\right)\end{array}$ & $\begin{array}{l}\text { among individuals within populations } \\
\qquad\left(F_{\mathrm{IS}}\right)\end{array}$ & within individuals \\
\hline All galathea and lachesis & $\begin{array}{l}0.1789^{* * *} \\
(0.1889)\end{array}$ & $\begin{array}{c}0.0875^{* * *} \\
(0.0758)\end{array}$ & $(0.7910)$ \\
\hline All galathea & $\begin{array}{c}0.1685^{* * *} \\
(0.1767)\end{array}$ & $\begin{array}{c}0.0858^{* * *} \\
(0.0748)\end{array}$ & $(0.7968)$ \\
\hline Sicily and Tunisia & $\begin{array}{c}0.0623^{* * *} \\
(0.0527)\end{array}$ & $\begin{array}{c}0.1111^{* * *} \\
(0.0882)\end{array}$ & (0.7059) \\
\hline Sicily & $\begin{array}{c}0.0476^{* * *} \\
(0.0345)\end{array}$ & $\begin{array}{l}0.0827^{*} \\
(0.0570)\end{array}$ & $(0.6325)$ \\
\hline Tunisia & $\begin{array}{c}0.0425^{* * *} \\
(0.0381)\end{array}$ & $\begin{array}{c}0.1252^{* * *} \\
(0.1075)\end{array}$ & $(0.7513)$ \\
\hline Morocco & $\begin{array}{l}0.0334^{* * *} \\
(0.0304)\end{array}$ & $\begin{array}{c}0.0408 \\
(0.0358)\end{array}$ & $(0.8427)$ \\
\hline Italy, Balkans, Central Europe & $\begin{array}{c}0.0951^{* * *} \\
(0.0939)\end{array}$ & $\begin{array}{c}0.0853^{* * *} \\
(0.0763)\end{array}$ & $(0.8174)$ \\
\hline Italy & $\begin{array}{c}0.0116 \\
(0.0112)\end{array}$ & $\begin{array}{l}0.1092^{* * *} \\
(0.1034)\end{array}$ & $(0.8438)$ \\
\hline Italy and S France & $\begin{array}{l}0.0142^{*} \\
(0.0135)\end{array}$ & $\begin{array}{c}0.1143^{* * *} \\
(0.1066)\end{array}$ & (0.8258) \\
\hline west Balkan group & $\begin{array}{l}0.0500^{* * *} \\
(0.0411)\end{array}$ & $\begin{array}{l}0.0999^{* *} \\
(0.0780)\end{array}$ & $(0.7028)$ \\
\hline east Balkan and Central Europe & $\begin{array}{c}0.0614^{* * *} \\
(0.0580)\end{array}$ & $\begin{array}{l}0.0673^{* * *} \\
(0.0597)\end{array}$ & $(0.8282)$ \\
\hline
\end{tabular}

F statistics (top line) with their respective variance values (in parenthesis below). Groupings following neighbour joining analysis and STRUCTURE plots (see Figures 1 and 2).

$*$ : $p<0.05 ; *: p<0.01 ;{ }^{* * *}: p<0.001$ 
structures of the neighbour joining phenogram and of STRUCTURE analyses (Table 4). Thus, these analyses strongly support (i) the genetic break in the Maghreb, (ii) the break between Sicily and mainland Italy, (iii) the differentiation into four genetic lineages in continental Europe, (iv) the cohesiveness between Sicily and Tunisia, (v) the lack of differentiation from the eastern Balkans via Romania to Central Europe and (vi) the strong genetic similarity between mainland Italy and southern France. The genetic differentiation within the seven groups at the lowest hierarchical level was low to moderate ranging from $F_{\mathrm{ST}}$ values of 0.0142 to 0.0614 (Table 3).

The genetic diversities among these genetic lineages showed significant differences (Table 2). Thus, the Morocco group showed the highest values achieved for $A, H_{\mathrm{e}}$ as well as $H_{\mathrm{o}}$, and the means for $P_{95}$ and $P_{\text {tot }}$ were above average. On the other extreme, Tunisia had the lowest means for $A, H_{\mathrm{e}}$ and $H_{\mathrm{o}}$, and the mean for $P_{95}$ was well below average; the genetic diversities of Tunisia were lower $\left(A, H_{\mathrm{e}}, H_{\mathrm{o}}, P_{\text {tot }}\right)$ or equal than in the otherwise rather similar populations from Sicily. The four groups from mainland Europe all have mostly intermediate genetic diversities scatted around the respective mean values.

\section{Species distribution modelling}

According to the classification of Swets [30], we received 'excellent' AUC values in our 100 models (average training $\mathrm{AUC}=0.927$, average test $\mathrm{AUC}=0.902$ ).
On average, the 'temperature annual range' had the highest explanatory power $(30.3 \%)$, followed by the 'minimum temperature of the coldest month' (16.8\%), the 'precipitation of the warmest quarter' (14.8\%), the 'annual precipitation' (10.2\%), the 'maximum temperature of the warmest month' (8.2\%) and the 'precipitation of the driest quarter' (7.2\%). All other variables contributed less than $5 \%$ each. The average minimum training presence was 0.05 , and the lowest 10 percentile training omission threshold was 0.36 .

The current potential distribution suggested by the SDM is highly coincident with the butterfly's recent range. The recent climatic niche over North Africa is displayed as two separate areas, in the West and East. Under palaeoclimatic conditions assumed to have prevailed 21,000 y BP (CCSM scenario), the potential distribution may have been much more restricted in Europe: Major parts of Central Europe changed into climatically unsuitable areas for $M$. galathea during the glacial period, while the southern European peninsulas (Iberia, Italy and the Balkan) retained suitable climatic conditions. Major parts of the Maghreb had a suitable climate for the butterfly being geographically more extended than today (Figure 3).

\section{Discussion}

The obtained allozyme data displayed in neighbour-joining phenograms, structure plots and hierarchical

Table 4 Hierarchical variance analyses of Melanargia galathea and M.lachesis among genetic groups

\begin{tabular}{|c|c|c|c|}
\hline Groups & $\begin{array}{c}\text { among } \\
\text { groups } \\
\left(F_{\mathrm{CT}}\right)\end{array}$ & $\begin{array}{c}\text { within } \\
\text { groups } \\
\left(F_{\mathrm{SC}}\right)\end{array}$ & $\begin{array}{c}\text { prop. of among groups variance of total variance } \\
\text { among pops. }\end{array}$ \\
\hline galathea vs lachesis & $\begin{array}{c}0.1811^{* * *} \\
(0.2308)\end{array}$ & $\begin{array}{c}0.1694^{* * *} \\
(0.1768)\end{array}$ & $56.6 \%$ \\
\hline Tunisia + Sicily vs rest of Europe & $\begin{array}{c}0.2256^{* * *} \\
(0.2786)\end{array}$ & $\begin{array}{c}0.0892^{* * *} \\
(0.0852)\end{array}$ & $76.6 \%$ \\
\hline Tunisia vs Morocco & $\begin{array}{c}0.2153^{* * *} \\
(0.2475)\end{array}$ & $\begin{array}{c}0.0387^{* * *} \\
(0.0349)\end{array}$ & $87.6 \%$ \\
\hline Tunisia vs Sicily & $\begin{array}{c}0.0338 \\
(0.0291)\end{array}$ & $\begin{array}{c}0.0445^{* * *} \\
(0.0370)\end{array}$ & $44.0 \%$ \\
\hline Sicily vs Italy & $\begin{array}{c}0.1797^{* * *} \\
(0.1928)\end{array}$ & $\begin{array}{c}0.0203^{* * *} \\
(0.0179)\end{array}$ & $91.5 \%$ \\
\hline Italy vs S France (Condat) & $\begin{array}{c}0.0107^{* * *} \\
(0.0102)\end{array}$ & $\begin{array}{c}0.0119^{* * *} \\
(0.0113)\end{array}$ & $47.4 \%$ \\
\hline Italy vs SW Alps (Col de Tende) & $\begin{array}{c}0.1726^{* * *} \\
(0.1993)\end{array}$ & $\begin{array}{c}0.0117^{* * *} \\
(0.0112)\end{array}$ & $94.7 \%$ \\
\hline east Balkans + Central Europe vs SW Alps (Col de Tende) & $\begin{array}{l}0.0615^{*} \\
(0.0621)\end{array}$ & $\begin{array}{c}0.0611^{* * *} \\
(0.0579)\end{array}$ & $51.8 \%$ \\
\hline $\begin{array}{l}\text { Italy vs SW Alps vs west Balkans vs east Balkans + } \\
\text { Central Europe }\end{array}$ & $\begin{array}{c}0.0798^{* * *} \\
(0.0813)\end{array}$ & $\begin{array}{c}0.0479^{* * *} \\
(0.0449)\end{array}$ & $64.4 \%$ \\
\hline east Balkans + Romania vs Central Europe & $\begin{array}{c}0.0066 \\
(0.0063)\end{array}$ & $\begin{array}{c}0.0581^{* * *} \\
(0.0548)\end{array}$ & $10.3 \%$ \\
\hline Morocco vs continental Europe & $\begin{array}{l}0.0269^{*} \\
(0.0271)\end{array}$ & $\begin{array}{c}0.0896^{* * *} \\
(0.0877)\end{array}$ & $23.6 \%$ \\
\hline
\end{tabular}

$F$ statistics (top line) with their respective variance values (in parenthesis below). Groupings following neighbour joining analysis and STRUCTURE plots (see Figures 1 and 2). 


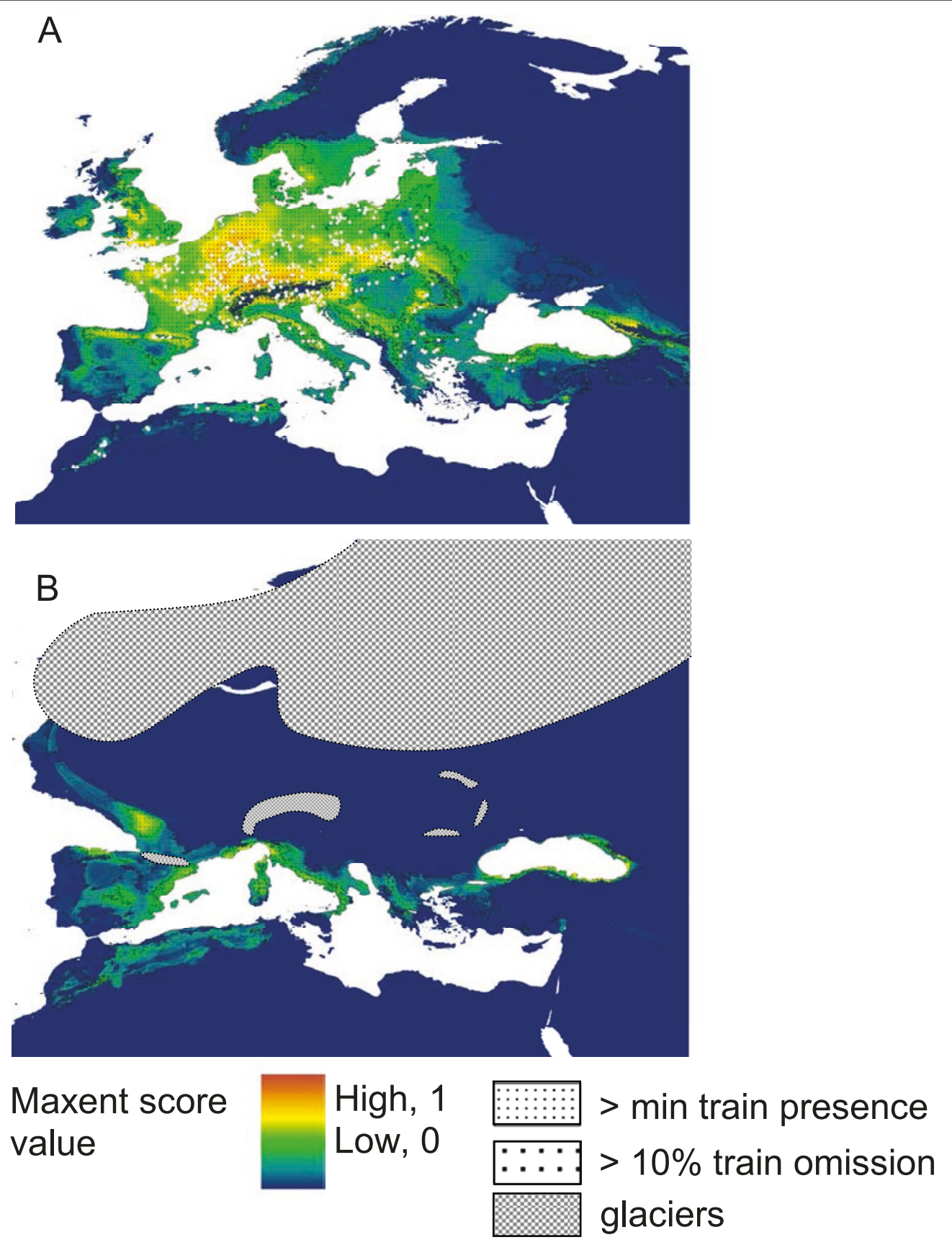

Figure 3 Distribution modelling of Melanargia galathea. Potential distributions of Melanargia galathea under (a) current and (b) palaeoclimatic conditions (CCSM). Species records used for model training are indicated as white dots (3a). Dark grey areas refer to occurrence probabilities above the average minimum training presence; black areas represent those above the 10 percentile training omission.

variance analyses indicate a profound genetic split between the two taxa, M. galathea and M. lachesis. Nazari et al. [31] supported this pattern by three lines of evidence: (i) differences of the male genitalia between $M$. lachesis and $M$. galathea, (ii) a stronger difference in wing patterns between these two taxa than between $M$. galathea population in Europe and the Maghreb and (iii) remarkable differences in DNA sequences of the nuclear $w g$ gene between $M$. lachesis and M. galathea, but no major differentiation between $M$. galathea samples from Europe and the Maghreb. However, the sequences of the two mtDNA genes cox 1 and $16 S$ contradict the common pattern of allozymes, genital structures, wing patterns and nuclear DNA sequences: This 
marker is not well distinguishing M. galathea from Europe and $M$. lachesis, but shows remarkable differences between Europe and the Maghreb with this split being dated back to the Messinia Salinity Crises more than 5 My ago [31]. Having in mind the differentiation pattern in all known marker systems, we believe that these two mtDNA lineages in the entire species complex might have originated at that time horizon, but were distributed to different geographical regions only much later by lineage sorting, maybe hereby exemplifying one case of the often observed difference between mtDNA on the one hand and nuclear DNA sequences, morphological characteristics and allozyme pattern on the other [32].

Our allozyme data further show strong differentiation within $M$. galathea into two major groups with respective subgroups: (i) Sicily - Tunisia with (i-a) Sicily and (i-b) Tunisia as well as (ii) all other M. galathea with (ii-a) Morocco, (ii-b) Italy with parts of southern France, (ii-c) western Balkan including the western Carpathian Basin, (ii-d) eastern Balkans with Romania and Central Europe, and (ii-e) the south-western Alps.

\section{Atlantic-Mediterranean origin of the M. galathea/lachesis species complex}

The recent geographic restriction of $M$. lachesis to Iberia and the highest genetic diversity of $M$. galathea in Morocco support the idea of a centre of origin of the entire species complex in this area. This assumption is further supported by other Melanargia species mostly endemic to the Atlantic-Mediterranean region (M. occitanica, $M$. ines) and other endemics to further Mediterranean refugia ( $M$. arge: peninsular Italy; $M$. pherusa: Sicily, $M$. larissa: Pontic-Mediterranean region and Iran). The onset of the differentiation between these sister species should be due to vicariance events most likely correlated with the onset of an ice age. If giving one glacial-interglacial cycle for the lowest level of differentiation (i.e. the subgroups within the two major $M$. galathea lineages), the most likely time horizon of this vicariance event is the onset of the Günz glaciation some 560,000 years BP [33] (Figure 4a). Since then, $M$. lachesis most likely has never expanded out of Iberia whereas M. galathea colonised most of Europe from its Maghreb expansion centre. Similar splits between Iberia and the Maghreb are commonly observed in many species groups [e.g. [13,34-36]].

\section{From the Maghreb to Europe}

The deepest split in the M. galathea populations is between the Sicily - Tunisia group and all the other populations. As this split is about twice the genetic differentiation among their subgroups and less than half of the distance against $M$. lachesis, the onset of the Riss glaciation (about $310 \mathrm{ky} \mathrm{BP)} \mathrm{[33]} \mathrm{might} \mathrm{be} \mathrm{the} \mathrm{trigger}$ for vicariance and thus the beginning of this differentiation. As (i) Iberia was continuously blocked for the expansion of $M$. galathea to Europe by $M$. lachesis [cf. 27] and (ii) all European M. galathea populations except Sicily are more similar to populations from Morocco than from Tunisia, a scenario with this split taking place in the Maghreb is little likely. This assumption is further supported by SDMs for ice age conditions predicting mostly continuous distributions over North Africa (Figure $3 \mathrm{~b}$ ) thus allowing vicariance in this region only during the relatively short interglacial stages. For these reasons, $M$. galathea must have reached Europe before the Riss glaciation.

As the region of the eastern Sahara in Egypt apparently always have been too dry for an expansion of $M$. galathea, this first expansion of M. galathea to Europe must have been from Tunisia to Sicily (Figure 4a), a sea strait known for biogeographical connections for many taxa [e.g. [15]; and references therein]. As the Strait of Sicily was considerably narrower during glacial periods due to eustatic sea level lowering, the transition from Mindel glaciation to Holstein interglacial with still low sea level but already higher temperatures might have been a suitable time period for this dispersal. After arrival to Sicily, the Holstein interglacial might have given suitable condition for the expansion of $M$. galathea over most parts of Europe, including the Balkans but excluding Iberia as this peninsula was already populated by $M$. lachesis (Figure 4a).

With the climatic cooling of the Riss ice age, which was considerably longer than the following Würm glaciation and had longer durations of minimum temperatures [33,37], M. galathea most probably was nearly extinct in Europe only surviving in the southernmost possible retreats in Sicily and the southern Balkans (Peleponnesos), but also in the Maghreb; M. lachesis could survive in southern Iberia (Figure 4b). This vicariance might be the origin of the two major European lineages of $M$. galathea with the eastern one by chance evolving similarly in allele frequencies as the Morocco lineage, with this similarity therefore not representing recent biogeographical connection between them. Riss vicariance events most likely have also been responsible for other differentiation processes as e.g. in the Polyommatus coridon /hispana complex [e.g. [38]].

\section{...and back to the Maghreb}

As the time for differentiation between the four $M$. galathea lineages from continental Europe is assumed to be the result of one glacial cycle (see above) and as the differentiation between populations from Sicily and Tunisia are in the same order of magnitude, we assume that the onset of this differentiation is in the same time frame. As the genetic diversity is significantly higher in 


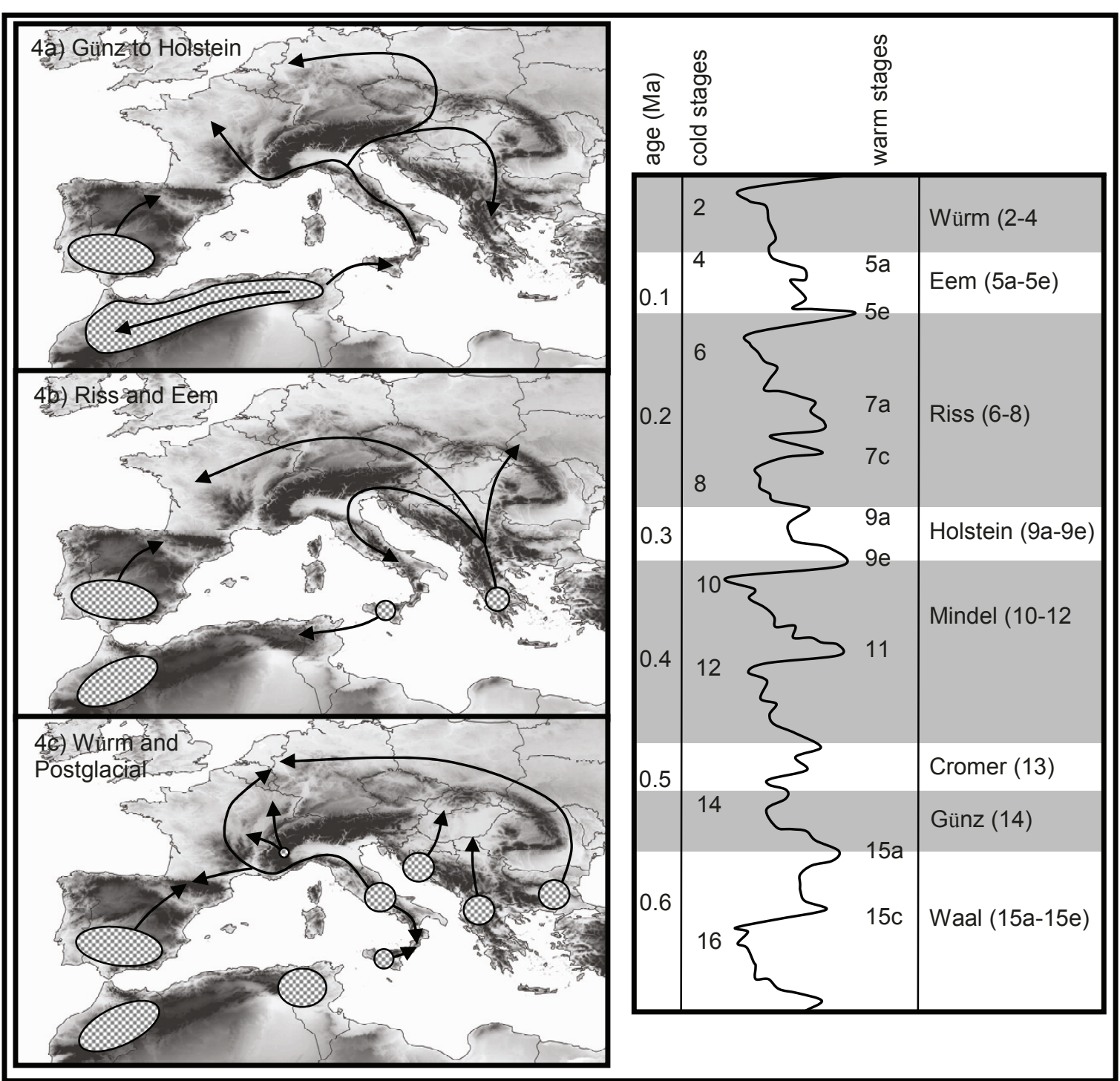

Figure 4 Biogeographic scenario of Melanargia galathea and $M$. lachesis. Range expansions and retractions of M. galathea and M. lachesis (on the Iberian Peninsula) during the past ice-ages (a-c) and fluctuations of marine isotope stages (d) (redrawn after Gibbard \& van Kolfschoten [33]). Refugia are marked by grey areas, expansions/retractions by arrows. 4a) Günz and Mindel refugia in Iberia (M. lachesis) and the Maghreb (M. galathea); expansion from the eastern Maghreb to Sicily during the Mindel/Holstein transition; Holstein expansion over Europe, but retraction in the Maghreb to the west. 4b) Riss refugia in Iberia (M. lachesis) and the western Maghreb, Sicily and southern Balkans (M. galathea; Riss/Eem transition expansion from Sicily to the eastern Maghreb; Eem expansion of the southern Balkan group over major parts of Europe including peninsular Italy. 4c) Würm refugia in Iberia (M. lachesis) as well as western and eastern Maghreb, Sicily, peninsular Italy, southwestern Alps and Balkan area (M. galathea); postglacial expansion from Iberia (M. lachesis), peninsular Italy and the Balkan area (M. galathea).

Sicily than in Tunisia and the warm and dry interglacial climatic conditions in Tunisia generally unsuitable for the survival of $M$. galathea, we assume that a colonisation most likely has taken place from Sicily to Tunisia. While the sea level was still considerably lowered at the transition from Riss to Eem thus facilitating dispersal between these two areas, this time period might be the most likely for this expansion event. During the following Eem interglacial, the Balkan refuge of M. galathea most probably could colonise most parts of Europe apart from Iberia and Sicily, which were occupied by other genetic lineages of this species complex (Figure $4 b)$.

\section{The existence of extra-Mediterranean refugia for} thermophilic taxa

During the Würm ice age, which was not more severe than the two previous glaciations but with a shorter 
maximum [33], the Marbled White butterflies were not that much pushed to the South than in the previous cases. This is well matching the remarkable differentiation of the species in Europe allowing to distinguish five lineages (see above), which most likely are the result of survival of the Würm ice age in a larger number of different refugia.

This pattern implies at least two different refugia at the Balkan Peninsula at the western and the eastern flank; more in detail analyses also support a third Balkan centre in the peninsula's southern parts [29] (Figure 4c). This pattern of multiple refugia in the Balkans was already erected by Reinig [39] postulating different centres of survival in the western, southern and eastern Balkans and was later supported by genetic analyses showing genetic divergences between these areas for a variety of different animal species [e.g. [18,40-42]].

Furthermore, different Würm refugia have to be postulated for Sicily and peninsular Italy, a pattern also repeated by other genetic analyses [e.g. [17,43]]. Furthermore, other genetic studies show a remarkable genetic differentiation in the southernmost parts of peninsular Italy [e.g. $[34,44,45]]$.

The last remaining lineage of $M$. galathea in the southwestern Alps most likely is not representing a Mediterranean refuge of this species, but an extra-Mediterranean refuge area at the southern slopes of the glaciated Alps (Figure 4c). As already shown by Steward and Lister [46], glacial survival of temperate species in Europe was not only possible in the classical Mediterranean refugia sensu de Lattin [47], but also in small climatically buffered pockets in more northern regions $[8,48,49]$. Recent works especially highlight the southern and south-eastern parts of the Alps of particular importance for additional Würm ice age refugia for temperate species [e.g. [42,50,51]], and also for species formerly thought to be of exclusive Mediterranean origin [e.g. [52,53]]. This apparently was also the case for the Marbled White.

\section{Postglacial expansion}

During the Postglacial, several lineages of $M$. galathea were mostly blocked in their expansion by other lineages representing the respective leading edges [cf. 54]. In the case of $M$. galathea in Morocco, their northwards expansion was blocked by $M$. lachesis distributed in Iberia. The lineage surviving in the eastern Balkans apparently had the most important impact in the recolonisation of more northern parts of Europe as its dispersal was not hampered by any major mountain obstacle [cf. 9] so that this lineage could expand throughout Central Europe to the western parts of Germany (Figure 4c). However, the samples of north-eastern France and southern Germany show an intermediate genetic structure between this lineage and the south-western Alps lineage, making hybrid origin of these populations rather likely and thus expansion of the southern Alps lineage over the chains of the Alps.

Also the Italian lineage could expand beyond its refugium to southern France. Therefore the entire region of northern France and southern Germany might be a zone of mixing between these three lineages. Hybrid zones between different taxa are frequently observed in this region [e.g. $[9,55]]$. Furthermore, the southernmost population in Calabria (southern Italy) has an intermediate genetic texture between the Italian and the Sicily group thus speaking for a postglacial contact and intermixing between these two groups in this region.

\section{Conclusion}

The hierarchical structure of our allozyme data set on $M$. galathea and M. lachesis is consistent with the chronology of the last four glacial-interglacial cycles. Based on this consistency, we derive the following scenario, which in our opinion is the most likely one: (i) The beginning of the Günz ice age might have affected the vicariance between the two species. (ii) M. galathea might have crossed from Tunisia to Sicily at the transition from Mindel ice age to Holstein interglacial and (iii) subsequently spread all over Europe, but retreated in the Maghreb to the higher elevations of the Atlas mountains. (iv) The members of this species complex survived the coldest periods of the Riss glaciation only in southern Iberia, Morocco, Sicily and the southern Balkans (Peleponnesos). (v) At the transition from Riss ice age to Eem interglacial, Tunisia was recolonised from Sicily. (vi) The southern Balkan group might have colonised major parts of Europe during the Eem interglacial including Italy and Central Europe. (vii) Populations of this group survived the Würm ice age in Italy, the southern margin of the Alps, the western and eastern flank of the Balkan peninsula; members of other lineages survived in Sicily, Tunisia, Morocco and Iberia. (viii) During the Postglacial, only the eastern Balkan and the Italian lineage showed major northwards range expansion. (ix) Hybridisation between lineages most probably occurred in western Central Europe and southern Calabria.

\section{Methods}

\section{Allozyme electrophoresis}

We scored banding patterns of allozyme polymorphisms analysed for 1,463 M. galathea specimens from 41 populations sampled across major parts of the Maghreb and Europe and one populations of M. lachesis (40 individuals) from the Spanish Pyrenees (see Figure 5 and Table 1). In total we analysed 15 enzyme systems: 6PGDH, ACON, FUM, G6PDH, GAPDH, AAT2, GPDH, PGI, HBDH, IDH1, IDH2, MDH1, MDH2, ME, and PEP. The data of $26 \mathrm{M}$. galathea populations and of 


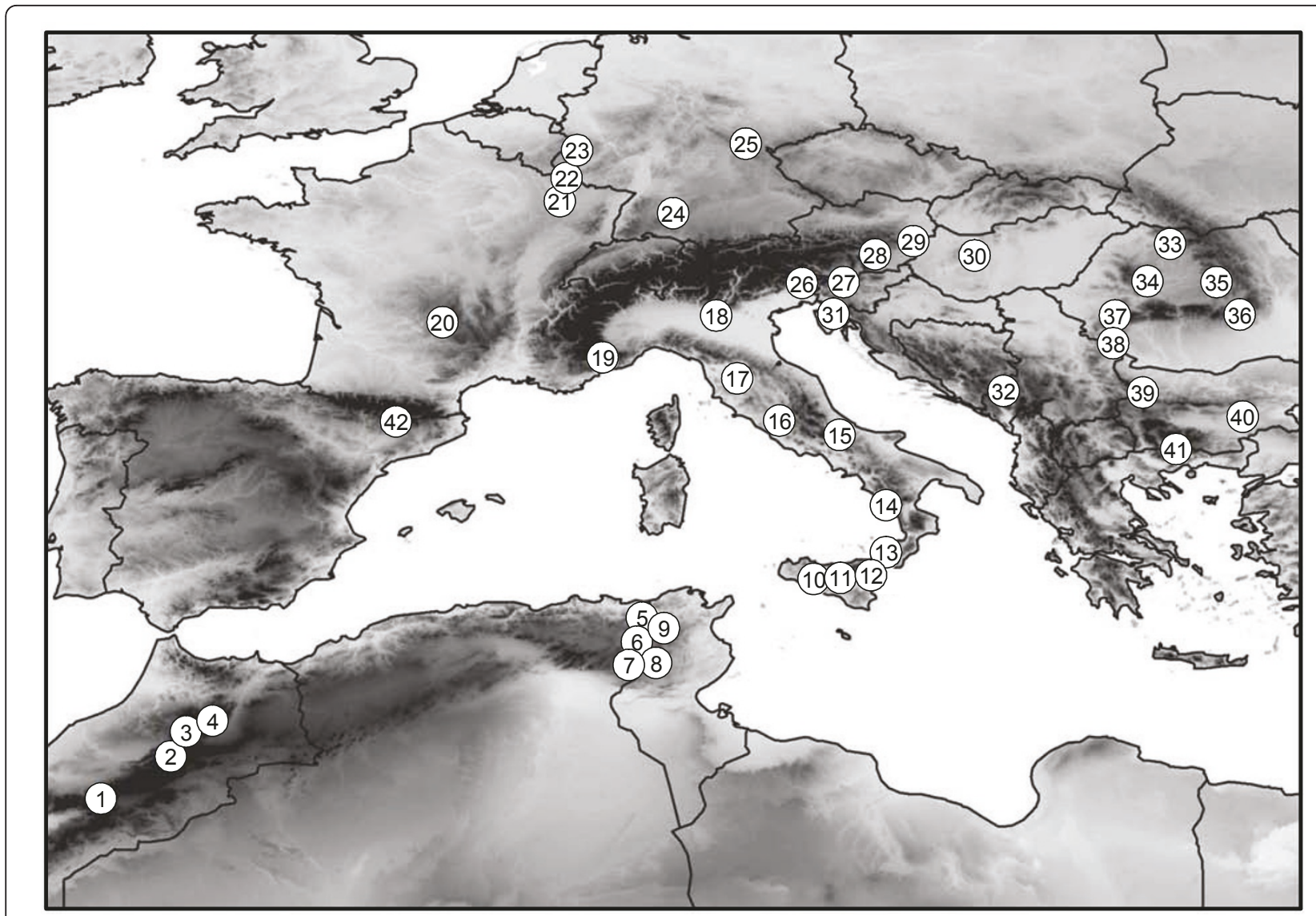

Figure 5 Sampling design of Melanargia galathea and M. lachesis. Geographical location of the sampled populations of M. galathea and M. lachesis (sample 42). Given numbers coincide with Table 1.

M. lachesis were taken from Habel et al. $[27,28]$ and Schmitt et al. [29]. Specimens were netted in the field from mid-May to the beginning of August between 2004 and 2010, frozen alive in liquid nitrogen or in a freezer and stored under these conditions until analysis. Standard procedures of allozyme electrophoresis were performed as described in Habel et al. [27].

\section{Statistics}

Alleles were labelled according to their relative mobility, starting with "1" for the slowest. All laboratory results were stored on cellulose acetate plates. These banding patterns were (re)analysed by one person (JCH). Allele frequencies, Nei's standard genetic distances [56] and parameters of genetic diversity (i.e. mean number of alleles per locus, $A$, expected heterozygosity, $H_{\mathrm{e}}$, and observed heterozygosity, $H_{\mathrm{o}}$, total percentage of polymorphic loci, $P_{\text {tot }}$, and percentage of polymorphic loci with the most common allele not exceeding 95\%, $P_{95}$ ) were computed with G-Stat [57]. As sample sizes do not differ significantly, the calculation of allelic richness correcting for population sizes was not necessary. For detecting differences of means of genetic diversities among genetic lineages and sublineages, we calculated U-tests using STATISTICA. Conventional F statistics, AMOVAs, hierarchical genetic variance analysis, tests of Hardy-Weinberg equilibrium and linkage disequilibrium were calculated with ARLEQUIN 3.1 [58]. Phenograms using the neighbour joining algorithm [59] were constructed with PHYLIP [60], including bootstrap-values (calculated based on 1,000 iterations). To define individual based genetic clusters we performed STRUCTURE analyses [61]. As burn-in and simulation lengths we used 100,000 and 300,000 iterations per run based on the admixture model with correlated gene frequencies comparing different groupings (from $\mathrm{K}=2$ to $\mathrm{K}=10$ ).

\section{Species Distribution Modelling}

Over the last few decades, Geographic Information System (GIS) based Species Distribution Models (SDMs) have become vital tools used to predict the potential distribution of species under current conditions and climate change scenarios [62-64]. In combination with palaeoclimatological data, SDMs have been suggested as 
a mean of inferring species' past distributions $[65,66]$, especially when combined with phylogeographic techniques [67].

We compiled a set of 3,483 species records of $M$. galathea from online data bases (Global Biodiversity Information Facility - GBIF; http://www.gbif.org) and our own field surveys. The accuracy of all records was checked in DIVA-GIS 5.4 [68] and only those which could be unambiguously assigned to a single grid cell with a resolution of $2.5 \mathrm{arc}$ min (ca. $4 \mathrm{~km}$ in the study area) were used for further processing. Since unequal spatial clumping of species records may cause problems when computing SDMs, the species records were filtered in geographic space, leaving only 1 record per 10 arc $\mathrm{min}$. The final data set comprised 535 records (Figure 3a) scattered all over the known range of the species in Europe and North Africa.

We obtained information on current and past climate as describedby the Community Climate System Model (CCSM; http://www.ccsm.ucar.edu) with a spatial resolution of 2.5 arc min from the Worldclim data base ([69]; http://www.worldclim.org). Original palaeoclimatological data were previously processed as described by Peterson and Nyári (2007) [70]. A total of 19 BIOCLIM variables were previously suggested as suitable for SDM computation $[71,72]$. However, inclusion of too many inter-correlated variables or biologically irrelevant predictors may hamper the transferability of SDMs through space and time [73-76]. Therefore, we first computed a pair-wise correlation matrix based on Pearson's correlation coefficients among all 19 predictor variables and excluded those with $R^{2}>0.75$. Subsequently, we chose a final set of eleven predictors describing biologically relevant climate conditions for the long-term persistence of $M$. galathea populations (i.e. annual mean temperature, maximum temperature of warmest month, minimum temperature of coldest month, temperature annual range, mean temperature of wettest quarter, mean temperature of driest quarter, annual precipitation, precipitation of wettest quarter, precipitation of driest quarter, precipitation of warmest quarter, precipitation of coldest quarter).

For SDM computation, Maxent 3.3.2 was applied $[77,78]$ using the default program settings. Random background records were automatically sampled by Maxent within the study area. Species records were split 100 times into $70 \%$ used for model training and 30\% for model evaluation via the area under the receiver operating characteristic curve (AUC; [79]). Subsequently, the average predictions for current and past conditions of the logistic output of the 100 models were computed and transformed into presence/absence maps applying the average minimum training presence and average $10 \%$ training omission as thresholds.

\section{Acknowledgements}

We acknowledge financial support by the German Academic Exchange Service (PostDoc Programme) and the Musée national d'histoire naturelle Luxembourg to $\mathrm{JCH}$ as well as from the Ministry of Education, Science, Youth and Culture of the Rhineland-Palatinate state of Germany to DR (project: 'Implications of global change for biological resources, law and standards'). We thank Claas Damken (Auckland, New Zealand) and Marc Meyer (Luxembourg) for field assistance. We thank the Fonds National de la Recherche Luxembourg for covering the publication fees.

\section{Author details}

${ }^{1}$ Musée national d'histoire naturelle Luxembourg, L-2160 Luxembourg, Luxembourg. ${ }^{2}$ Terrestrial Ecology Unit, Department of Biology, Gent University, B-9000 Gent, Belgium. ${ }^{3}$ Department of Biogeography, Trier University, D-54296 Trier, Germany. ${ }^{4}$ Zoologisches Forschungsmuseum Alexander Koenig, Adenauerallee 160, 53113 Bonn, Germany.

\section{Authors' contributions}

JCH sampled and analysed M. galathea-individuals, performed statistics, datainterpretation, and has written major parts of the manuscript. TS sampled individuals, and supported the work by data-interpretation and writing. DR performed species distribution models, and LL strengthened the significance of the manuscript by data-interpretation and by upgrading the linguistic style. All authors red and approved the final version of the manuscript.

Received: 27 January 2011 Accepted: 21 July 2011

Published: 21 July 2011

\section{References}

1. Lomolino MV: Biogeography. Sinauer Assn 2005, 465

2. Reinig WF: Die Holarktis. Gustav-Fischer-Verlag 1937, Jena.

3. De Lattin G: Grundriß der Zoogeographie. Verlag Gustav Fischer 1967, Jena.

4. Dennis RLH, Williams WR, Shreeve TG: A multivariate approach to the determination of faunal units among European butterfly species (Lepidoptera: Papilionoidea, Hesperioidea). Zoological Journal of the Linnean Society 1991, 101:1-49.

5. Hewitt GM: Some genetic consequences of ice ages, and their role in divergence and speciation. Biological Journal of the Linnean Society 1996, 58:247-276.

6. Taberlet P, Fumagalli L, Wust-Saucy A-G, Cosson J-F: Comparative phylogeography and postglacial colonization routes in Europe. Molecular Ecology 1998, 7:453-464.

7. Hewitt GM: Genetic consequences of climatic oscillation in the quaternary. Phil Trans R Soc Lond B 2004, 359:183-195.

8. Schmitt T: Molecular biogeography of Europe: Pleistocene cycles and postglacial trends. Frontiers in Zoology 2007, 4:11

9. Hewitt GM: Post-glacial re-colonization of European biota. Biological Journal of the Linnean Society 1999, 68:87-112.

10. Hewitt GM: The genetic legacy of the Quaternary ice ages. Nature 2000, 405:907-913.

11. Cosson J-F, Hutterer R, Libois R, Sara M, Taberlet $P$, Vogel $P$ : Phylogeographical footprint of the Strait of Gibraltar and Quaternary climatic fluctuations in the western Mediterranean: a case study with the greater white-toothed shrew, Crocidura russula (Mammalia: Soricidae). Molecular Ecology 2005, 14:1151-1162.

12. Carranza S, Arnold EN, Pleguezuelos JM: Phylogeny, biogeography, and evolution of two Mediterranean snakes, Malpolon monspessulanus and Hemorrhois hippocrepis (Squamata, Colubridae), using mtDNA sequences. Molecular Phylogenetics and Evolution 2006, 40:532-546.

13. Carranza S, Harris DJ, Arnold EN, Batista V, Gonzalez de la Vega JP. Phylogeography of the lacertid lizard, Psammodromus algirus, in Iberia and across the Strait of Gibraltar. Journal of Biogeography 2006, 33:1279-1288.

14. Fritz U, Barata M, Busack SD, Fritsch G, Castilho R: Impact of mountain chains, sea straits and peripheral populations on genetic and taxonomic structure of a freshwater turtle, Mauremys leprosa (Reptilia, Testudines, Geoemydidae). Zoologica Scripta 2006, 35:97-108.

15. Franck P, Garnery L, Loiseau A, Oldroyd BP, Hepburn HR, Solignac M, Cornuet J-M: Genetic diversity of the honeybee in Africa: microsatellite and mitochondrial data. Heredity 2001, 86:420-430. 
16. Habel JC, Rödder D, Scalercio S, Meyer M, Schmitt T: Strong genetic cohesiveness between Italy and the Maghreb in four butterfly species. Biological Journal of the Linnean Society 2010, 99:818-830.

17. Santucci F, Emerson B, Hewitt GM: Mitochondrial DNA phylogeography of European hedgehogs. Molecular Ecology 1998, 7:1163-1172.

18. Seddon JM, Santucci F, Reeve NJ, Hewitt GM: DNA footprints of European hedgehogs, Erinaceus europaeus and E. concolor. Pleistocene refugia, postglacial expansion and colonization routes. Molecular Ecology 2001 10:2187-2198.

19. Colliard C, Sicilia A, Turrisi GF, Arculeo M, Perrin N, Stöck M: Strong reproductive barriers in a narrow hybrid zone of West-Mediterranean green toads (Bufo viridis subgroup) with Plio-Pleistocene divergence. BMC Evolutionary Biology 2010, 10:232.

20. Veith M, Mayer C, Samraoui B, Barrosso DD, Bogaerts S: From Europe to Africa and vice versa: evidence for multipe intercontinental dispersal in ribbed salamanders (Genus Pleurodeles). Journal of Biogeography 2004, 31:159-171.

21. Paulo OS, Pinto I, Bruford MW, Jordan WC, Nichols RA: The double origin of Iberian peninsular chameleons. Biological Journal of the Linnean Society 2008, 75:1-7.

22. Tennent J: The butterflies of Morocco, Algeria and Tunisia. Gem publishing Company Wallingford; 1996

23. Tolman T, Lewington R: Field guide butterflies of Britain and Europe. Harper Collins Publishers London; 1997.

24. Asher J, Warren M, Fox R, Harding P, Jeffcoate G, Jeffcoate S: The millennium atlas of butterflies in Britain and Ireland Oxford University Press Oxford; 2001.

25. García-Barros E, Munguira ML, Martín Cano J, Romo Benito H, GarciaPereira P, Maravalhas ES: Atlas de las mariposas diurnas de la Península Ibérica e islas Baleares (Lepidoptera: Papilionoidea and Hesperioidea). In Monografias Sociedad Entomológica. Volume 11. Aragonesa; 2004.

26. Buszko J: Atlas rozmieszczenia motyli dziennych w Polsce (Lepidoptera: Papilionidae, Hesperiidae). Edycja Turpress 1997, Torun.

27. Habel JC, Schmitt T, Müller P: The fourth paradigm pattern of postglacial range expansion of European terrestrial species: The phylogeography of the Marbled White butterfly (Satyrinae, Lepidoptera). Journal of Biogeography 2005, 32:1489-1497.

28. Habel JC, Meyer M, El Mousadik A, Schmitt T: Africa goes Europa: The complete phylogeography of the Marbled White butterfly species complex Melanargia galathea /lachesis. Organisms, Diversity and Evolution 2008, 8:121-129.

29. Schmitt T, Habel JC, Zimmermann M, Müller P: Genetic differentiation of the marble white butterfly, Melanargia galathea, accounts for glacial distribution patterns and postglacial range expansion in southeastern Europe. Molecular Ecology 2006, 15:1889-1901.

30. Swets K: Measuring the accuracy of diagnostic systems. Science 1988, 240:1285-1293.

31. Nazari V, Hagen WT, Bozano GC: Molecular systematics and phylogeny of the Marbled Whites (Lepidoptera: Nymphidae, Satyrinae, Melanargia Meigen). Sysematics Entomology 2009, 35:132-147.

32. Hein J, Schierup MH, Winf C: Gene genealogies, variation and evolution A primer in coalescent theory. Oxford University Press, Oxford; 2005.

33. Gibbard P, van Kolfschoten T: The Pleistocene and Holocene epochs. In A geologic time scale. Volume 98. Edited by: Gradstein FM, Ogg JG, Smith AG. Cambridge University Press, Cambridge; 2004:441-452.

34. Steinfartz S, Veith M, Tautz D: Mitochondrial sequence analysis of Salamandra taxa suggests old splits of major lineages and postglacial recolonizations of Central Europe from distinct source populations of Salamandra salamandra. Molecular Ecology 2000, 9:397-410.

35. Carranza S, Wade E: Taxonomic revision of Algero-Tunisian Pleurodeles (Caudata: Salamandridae) using molecular and morphological data. Revalidation of the taxon Pleurodeles nebulosus (Guichenot, 1850). Zootaxa 2004, 488:1-24.

36. Fromhage $L$, Vences $M$, Veith $M$ : Testing alternative vicariance scenarios in Western Mediterranean discoglossid frogs. Molecular Phylogenetics and Evolution 2003, 31:308-322.

37. Quante M: The changing climate: future. In Relict species - phylogeography and conservation biology. Edited by: Habel JC, Assmann T. Springer Heidelberg; 2010:9-56.

38. Schmitt T, Varga Z, Seitz A: Are Polyommatus hispana and Polyommatus slovacus bivoltine Polyommatus coridon (Lepidoptera: Lycaenidae)? The discriminatory value of genetics in the taxonomy. Organisms, Diversity and Evolution 2005, 5:297-307.

39. Reinig WF: Chorologische Voraussetzungen für die Analyse von Formenkreisen. Syllegomena Biologica, Festschrift für O Kleinschmidt 1950, 346-378.

40. Lenk P, Fritz $U$, Joger $U$, Winks M: Mitochondrial phylogeography of the European pond turtle, Emys orbicularis (Linnaeus 1758). Molecular Ecology 1999, 8:1911-1922.

41. Seddon JM, Reeve N, Hewitt GM: Caucasus Mountains divide postulated postglacial colonization routes in the white-breasted hedgehog, Erinaceus concolor. Journal of Evolutionary Biology 2002, 15:463-467.

42. Pinceel J, Jordaens K, Pfenninger M, Backeljau T: Rangewide phylogeography of a terrestrial slug in Europe: evidence for Alpine refugia and rapid colonization after the Pleistocene glaciations. Molecular Ecology 2005, 14:1133-1150.

43. Cooper SJ, Ibrahim KM, Hewitt GM: Postglacial expansion and genome subdivision in the European Grasshopper Chorthippus parallelus. Molecular Ecology 1995, 4:49-60.

44. Podnar M, Mayer W, Tvrtkovic N: Phylogeography of the Italian wall lizard, Podarcis sicula, as revealed by mitochondrial DNA sequences. Molecular Ecology 2005, 14:575-588.

45. Canestrelli D, Cimmaruta R, Costantini V, Nascetti G: Genetic diversity and phylogeography of the Apennine yellow-bellied toad Bombina pachypus, with implications for conservation. Molecular Ecology 2006, 15:3741-3754.

46. Steward JR, Lister AM: Cryptic northern refugia and the origins of the modern biota. Trends in Ecology and Evolution 2001, 16:608-613.

47. de Lattin G: Beiträge zur Zoogeographie des Mittelmeergebietes. Verhandlungen der deutschen Zoologischen Gesellschaft, Kiel 1949, 143-151.

48. Nève $G$, Verlaque R: Genetic differentiation between and among refugia. In Relict species - phylogeography and conservation biology. Edited by: Habel JC, Assmann T. Springer Heidelberg; 2010:277-294.

49. Habel JC, Augenstein B, Nève G, Rödder D, Assmann T: Population genetics and ecological niche modelling reveal high fragmentation and potential future extinction of the endangered relict butterfly Lycaena helle. In Relict species - phylogeography and conservation biology. Edited by: Habel JC, Assmann T. Springer Heidelberg; 2010:417-440.

50. Schmitt T, Seitz A: Allozyme variation in Polyommatus coridon (Lepidoptera: Lycaenidae): identification of ice-age refugia and reconstruction of post-glacial expansion. Journal of Biogeography 2001 28:1129-1136.

51. Gratton P, Konopinski MK, Sbordoni V: Pleistocene evolutionary history of the Clouded Apollo (Parnassius mnemosyne): genetic signatures of climate cycles and a 'time-dependent' mitochondrial substitution rate. Molecular Ecology 2008, 17:4248-4262.

52. Magri D: Patterns of post-glacial spread and the extent of glacial refugia of European beech (Fagus sylvatica). Journal of Biogeography 2008, 35:450-463.

53. Magri D, Vendramin GG, Comps B, Dupanloup I, Geburek T, Gomory D, Latalowa M, Litt T, Paule L, Roure JM, Tantau I, van der Knaap WO, Petit RJ, de Beaulieu JL: A new scenario for the Quaternary history of European beech populations: palaeobotanical evidence and genetic consequences. New Phytologist 2006, 71:199-221.

54. Hampe A, Petit RJ: Conserving biodiversity under climate change: the rear edge matters. Ecology Letters 2005, 8:461-467.

55. Habel JC, Dieker P, Schmitt T: Biogeographical connections between the Maghreb and the Mediterranean peninsulas of southern Europe. Biological Journal of the Linnean Society 2009, 98:693-703.

56. Nei M: Genetic distances between populations. The American Naturalist 1972, 106:283-291.

57. Siegismund HR, Müller J: Genetic structure of Gammarus fossarum populations. Heredity 1991, 66:419-436.

58. Excoffier L, Larval G, Schneider S: Arlequin ver. 3.0: an integrated software package for population genetics data analysis. Evolutionary Bioinformatics Online 2005, 1:47-50.

59. Saitou N, Nei M: The neighbor-joining method: a new method for reconstructing phylogenetic trees. Molecular Biology and Evolution 1987, 4:406-425.

60. Felsenstein J: PHYLIP (Phylogeny Inference Package) Ver. 3.5.c. Department of Genetics, University of Washington Seattle, Washington; 1993.

61. Pritchard JK, Stephens M, Donnelly P: Inference of population structure using multilocus genotype data. Genetics 2000, 155:945-955. 
62. Guisan A, Zimmermann N: Predictive habitat distribution models in ecology. Ecological Modelling 2000, 135:147-186.

63. Jeschke JM, Strayer DL: Usefulness of bioclimatic models for studying climate change and invasive species. Annals of the New York Academy of Sciences 2008, 1134:1-24.

64. Elith J, Leathwick JR: Species distribution models: Ecological explanation and prediction across space and time. Annual Reviews in Ecology, Evolution and Systematics 2009, 40:677-697.

65. Waltari E, Hijmans RJ, Peterson AT, Nyári AS, Perkins SL, Guralnick RP: Locating pleistocene refugia: Comparing phylogeographic and ecological niche model predictions. PLoS one 2007, 7:1-11.

66. Hijmans RJ, Guarino L, Jarvis A, O'brien R, Mathur P, Bussink C, Cruz M, Barrantes I, Rojas E: DIVA-GIS version 5.2 manual. 2005.

67. Nogués-Bravo D: Predicting the past distributions of species climatic niches. Global Ecology and Biogeography 2009, 18:521-531.

68. Rödder D, Weinsheimer F, Lötters S: Molecules meet macroecology combining species distribution modells and phylogeographic studies. Zootaxa 2010, 2426:54-60.

69. Hijmans RJ, Cameron SE, Parra JL, Jones PG, Jarvis A: Very high resolution interpolated climate surfaces for global land areas. International Journal of Climatology 2005, 25:1965-1978.

70. Peterson AT, Nyári ÁS: Ecological niche conservatism and pleistocene refugia in the thrush-like mourner, Shiffornis sp., in the neotropics. Evolution 2007, 62:173-183

71. Busby JR: Bioclim - a bioclimatic analysis and prediction system. In Nature conservation: Cost effective biological surveys and data analysis. Edited by: CR Margules, MP Austin. CSIRO, Melbourne; 1991:64-68.

72. Beaumont LJ, Hughes L, Poulsen M: Predicting species distributions: Use of climatic parameters in bioclim and its impact on predictions of species' current and future distributions. Ecological Modelling 2005 186:250-269.

73. Heikkinen RK, Luoto M, Araújo MB, Virkkala R, Thuiller W, Sykes MT: Methods and uncertainties in bioclimatic envelope modeling under climate change. Progress in Physical Geography 2006, 30:751-777.

74. Rödder D, Lötters S: Niche shift versus niche conservatism? Climatic charactersistics of the native and invasive ranges of the mediterranean house gecko (Hemidactylus turcicus). Global Ecology and Biogeography 2009, 18:674-687.

75. Rödder D, Schmidtlein S, Veith M, Lötters S: Alien invasive slider turtle in unpredicted habitat: A matter of niche shift or of predictors studied? PLOS one 2009, 4:e7843.

76. Rödder D, Lötters S: Explanative power of variables used in species distribution modelling: An issue of general model transferability or niche shift in the invasive greenhouse frog (Eleutherodactylus planirostris). Naturwissenschaften 2010, 97:781-796.

77. Phillips SJ, Anderson RP, Schapire RE: Maximum entropy modeling of species geographic distributions. Ecological Modelling 2006, 190:231-259.

78. Phillips SJ, Dudík M: Modeling of species distributions with Maxent: new extensions and a comprehensive evaluation. Ecography 2010, 31:161-175.

79. Pearce J, Ferrier S: An evaluation of alternative algorithms for fitting species distribution models using logistic regression. Ecological Modelling 2000, 128:128-147.

doi:10.1186/1471-2148-11-215

Cite this article as: Habel et al:: From Africa to Europe and back: refugia and range shifts cause high genetic differentiation in the Marbled White butterfly Melanargia galathea. BMC Evolutionary Biology 2011

\section{Submit your next manuscript to BioMed Central and take full advantage of:}

- Convenient online submission

- Thorough peer review

- No space constraints or color figure charges

- Immediate publication on acceptance

- Inclusion in PubMed, CAS, Scopus and Google Scholar

- Research which is freely available for redistribution 